\title{
Facebooking for a More Lively Interaction in Literature Classroom
}

\section{Logenthini Mariappan, Abd Ghani Bin Abu, Ainon Binti Omar}

Faculty of Languages and Communication, Universiti Pendidikan Sultan Idris (UPSI), Tanjong Malim, Malaysia

Email: logen1702@gmail.com

How to cite this paper: Mariappan, L., Abu, A. G. B., \& Omar, A. B. (2017). Facebooking for a More Lively Interaction in Literature Classroom. Creative Education, $8,749-763$.

https://doi.org/10.4236/ce.2017.85056

Received: February 6, 2017

Accepted: April 27, 2017

Published: April 30, 2017

Copyright () 2017 by authors and Scientific Research Publishing Inc. This work is licensed under the Creative Commons Attribution International License (CC BY 4.0).

http://creativecommons.org/licenses/by/4.0/

\section{(c) (7) Open Access}

\begin{abstract}
Social networking sites appear to be the most widely accessed and they have been the new trend of today's communication. Facebook as one of the social networking sites has captured the attention of educators and policy-makers as an alternative tool for language teaching and learning. The use of Facebook in learning Literature is considered as beneficial and interesting. Moreover it gives chance for students to get more understanding of the novel and its events. This research; therefore, set its objective to explore the use of Facebook as a supplementary resource for lower secondary school students to learn English Literature. Quasi-experimental design was used for this purpose and a number of 60 lower secondary school students were chosen using purposive sampling methods. The subjects were divided into 30 students for the treatment and control groups equally. The research instrument used was pretest-posttest. The findings showed that there was improvement in achievement for treatment group. The study also examines the students' perceptions on the use of Facebook in learning literature. The total number of respondents who participated in this study was 30 and the students' perceptions were measured through a questionnaire comprising 30 items. The findings indicated that Facebook can be effective in learning novel. The results showed that via Facebook the students can widen their knowledge on Literature novel and the students can understand what the novel revolves around. This study recommends the use of Facebook as a Literature learning tool for lower secondary school students.
\end{abstract}

\section{Keywords}

Facebook, Literature, Learning, Perception, Social Networking Site

\section{Introduction}

In this era of globalization, internet has become a mutual medium for people to 
communicate with each other. Today's students are used to live with the internet technologies in their everyday life thus they do not have any problem in using technology in the classroom. In dealing with the internet technologies, social networks appear to be the most commonly accessed and they have been the new trend of today's communication.

It was found that $93 \%$ of young people ages $12-17$ go online and $73 \%$ of them frequently visit social networking sites (Lenhart et al., 2010). In that case, Facebook has been one of the most important Social Networking Site for past decade. Facebook was opened to the public in 2006 and the reports showed that it has achieved 1.06 billion monthly active users (Facebook, 2013).

Our internet generation students expecting more from the class and their strong interest and frequent engagements towards Social Networking Site (SNS) have attracted both educators as well as academic researchers' attention. In addition to that, since Facebook has large number of users worldwide, teachers should accept the fact that Facebook has a abundant potential as a tool to be used in education. Studies have reported that students were seen to be passive and they were unable to respond critically. Literature lessons were often too teacher-centred and thus labeling teachers to be dull and less creative (Sidhu, 2003). Since online technology makes the class interactive and holistic (Plato's Principles of education) then, it will be possible if the teachers make use of those technologies and realize the implications (Chapelle, 2003) for better enhancement of literature lessons.

The researchers have been teaching ESL for many years. They noticed that students lack of competence in English with special regards to Literature despite the fact that all the efforts by teachers, parents and schools have been made to help them enhance their learning. The importance of language will only realized by the students if the teaching and learning process take part in a correct way. Additionally, English Literature teaching syllabus outlines learning outcomes which are the expected attainment targets to be achieved by the students as a result of teacher instruction (Ministry of Education Singapore, 2013). Thus this shows that the learning outcomes will only be achieved from the result of how is the instruction of the teachers.

The application of certain methods and the teaching styles will give an impact from different perspectives such as students' interest and comprehension towards literary text. Thus the language teachers need to find proper ways to get the students to have interest in reading literary text. If they managed to do so, then the teachers won $50 \%$ of up skilling literature skills among students (Mahzan, 2005).

Moreover, Khalid \& Kabilan (2012), conducted a survey on EFL learners and they found out that EFL learners faced many problems in English Literature classes. First, they found out that literature courses are complex in nature, and the students want a technique that can facilitate them to understand better about the courses. Second, it was found there is no enjoyment in the literature learning process therefore the students feel bored in the classroom. Finally students faced 
problems in the literature classroom due to the teaching methods where it followed the same routine and they suggested using another teaching technique in literature classes.

According to Mabunda (2010), teachers who are teaching English Literature find it challenging to make the students appreciate English Literature and students in Saudi Arabia have been shown to perform below average in Literature-novel courses. It is found that the problem is not only with the students to understand the novel courses but also with the teachers where they too have difficulties in conveying Literature to the students.

Based on this problem, the researchers found that introducing teaching tool where the students are interested in will solve this problem. Apart from that, due to the features offered, the researchers of this study believe that Facebook possesses huge potential as an educational tool. Thus the researchers decided to study on the use of Facebook in learning Literature.

The focus of this study was limited to the use of Facebook group only. Other social networking sites such as MySpace and Tumble were excluded. The researchers chose Facebook as a tool to learn Literature because Facebook is currently the most popular online social networking site among students (Chen et al., 2010). For this study the researchers created a Facebook group specifically for the purpose of providing students with contents and directions of learning Literature. The researchers are the facilitator for the Facebook Group and give immediate feedback on the interaction in that group. In order to facilitate the investigation regarding the use of Facebook Group in learning Literature, the researchers form the following research questions:

a) What is the effect of using Facebook on improving students' performance in Literature?

b) What are the perceptions of the students in incorporating Facebook in their learning of Literature?

The motive of carrying out this research is to figure out if the implementation of Facebook group can help ESL students with their learning of Literature and their perceptions towards the usage of Facebook in learning Literature. The participants in this study are from schools situated in Klang district. This research will be dealing only with Facebook.

\section{Literature Review}

A few decades ago, the best way to keep in touch with our professors was to go to their office but nowadays it is commonly believed that students just need to use their computer and everything is done. In today's trend, Social Networking Sites (SNS) has become one of the most important communication tools. Facebook is considered as the most widely used social networking sites among all due to its constantly increasing active members (Noyes, 2015). It can be a promising educational tool to be used in today's information era too.

Results of past Literatures show that Facebook has the potential to be used as a platform for online academic discussions (Lim, 2010). As said by Zhao et al. 
(2008) Facebook has gained popularity among teenagers and almost all teenagers have a Facebook account and spend hours in there.

Previous studies on the use of Facebook as an educational tool show that students get benefits in using Facebook in their learning (Madge et al., 2009). Furthermore, by inserting Facebook in their teaching tool, teachers can create a good learning environment as Facebook is useful for learning environment (Kabilan, Ahmad, \& Abidin, 2010). In that case, Facebook will be able to enhance teaching and learning practice (Hamid et al., 2011).

Most importantly, Facebook is a social networking site that facilitates online communication among L2 learners. According to Blattner \& Fiori (2009), Facebook can be used to improve students' performance of the English language, increase motivation and trigger authentic language interaction.

Facebook as a social networking site not only benefits the students but also pose challenges for them as Bugeja (2006) states that using Facebook in teaching can be used as a tool and also can be a distraction in the classroom as well. Likewise, Hurt et al. (2012) states that social media might provide too much encouragement and at the same time can distract students from completing the coursework. In order to address this issue, Bugeja (2006) gives solution for this problem where he states that there is a need to foster the students' ability to discern when and where technology will be appropriate and inappropriate.

Kirschner \& Karpinski (2010) state that students can post inappropriate pictures of themselves on their profile and Slonje, Smith \& Frisen (2013) state that spending hours on social media can lead to addiction and perhaps cause health problems. Although these risks are admissible, evidence of the positive effects of social media used in this study (Junco et al., 2011) states that students' engagement, involvement, satisfaction and grades will increase if the social media is very well used.

Simpson (2012) has indicated in his study that the instructors must familiarize themselves with the program first in order to employ Facebook correctly. Moreover, upon the entire factors, the participants' laziness is one of the factorsthat should be given an attention as it can be problematic for learning process. In addition to that, Boogart \& Robert (2006) concluded that the use of Facebook have unfavorable impacts on the academic performance of the students. Subsequently, Grabmeier (2009) found that students achieving lower GPAs were mostly those login any social networking site.

However many researchers found that there is a positive recommendation between the use of Social Networking Sites and academic performance of the students. As stated by Linda (2006), students scored higher on reading skills test and achieved high grades as well by using more internets. Moreover, according to Ellison et al. (2007), it was found that that the usage of Social Networking sites is helpful for cure in case of some psychological problems including low life satisfaction and low self-esteem.

As stated by Roblyer et al. (2010), Social Networking Sites also provide a rich means of interaction between teachers and students. In addition to that, by im- 
plementing Facebook into classroom, it could make the learning interactive, personalized and holistic (Roth, 2009). Our internet generation students are not only expecting lectures and books from a class but they are expecting more than that. Traditional classrooms are losing the ability to motivate and challenge our new generation students. Today's students are used to live with the internet technologies in their everyday life. These students are considered as digital natives who will enjoy a computer and internet resources to be used in their classrooms (Luke, 2006).

It can be said that bringing technologies in teaching can really make the class more interesting and motivated for the students. As suggested by Chapelle (2003), teachers could make use of these technologies and discover their implications for language teachers and researchers. Therefore the researchers try to shed the light on the importance of using one of the social networking sites which is Facebook as an effective tool to learn literature in this study. Bear in mind, by using Facebook in learning Literature, it provides opportunities for the students to use it outside the classroom and it can be helpful for the students in understanding their lessons more and to manage literature classes more.

\section{Research Methodology}

Total of 60 students participated in this research. Those students were chosen using purposive sampling. The students for experimental group were chosen based on certain criteria such as the years of becoming Facebook member, the number of times the respondents logged in to their Facebook and the competency level in using Facebook. In addition to that, all of them were students from Klang Schools. A quasi-experimental design utilized where pretest and posttest were used. The respondents were divided into 2 groups which consist of 30 students in a group. Before the lesson, the respondents from both groups were given a pretest on the Literature novel. After that, one group was taught using traditional approach where else the other group taught by using Facebook for eight weeks. A Facebook group was created for the respondents in focus group and they were required to participate and involve in lessons prepared by the researchers. In order to create a lively learning environment and enable participants to experience how Facebook group can be used to improve literary skills particularly in a Malaysian ESL context, the participants from the focus group were encouraged to take part in giving opinions, contributing ideas and comments actively.

After the eight weeks of lesson, both controlled and focused group were given a posttest on the Literature lesson learnt. In the final stage, the participants from experimental group were required to respond to 30 item questionnaires which has been pilot tested. The questionnaires consist of two parts. Part one solicited demographic information of the students whether or not each participant has a Facebook account, how often they log on to Facebook, whether or not they are familiar with the Facebook group and if they were part of any other Facebook group apart from the one created for the purpose of this study [appendix]. 
Part two comprised 30 items with a 5 Likert scale of "Strongly Disagree", "Disagree", "Undecided", “Agree" and "Strongly Agree". Those 30 items asked about the respondents' perceptions towards the use of Facebook. As for the demographic data, frequency and percentages were used where else for the description of the other items, mean scores, frequency and percentages were used to describe the students' views on the use of Facebook as a mean for learning literature.

\section{Findings}

The findings are presented in three sections. The first one presents the students' general performance on Facebook. The second section answers the questions whether or not Facebook as more lively interaction facilitates learning English Literature among Form 3 students. The third section investigates students' perceptions towards the use of Facebook in learning Literature.

\subsection{Students' General Activity on Facebook}

It was found that the majority of the students (93.3\%) who had a Facebook account said that they joined FB more than a year. Only $6.7 \%$ of the students stated that they have been the FB members less than a year. Table 1 presents responses of respondents regarding the length of time as a FB member.

Table 2 below presents data regarding the number of times the respondents logged in to their Facebook accounts.

It shows that the majority of the students were active members of Facebook. It is seen that 16 students (53.3\%) logged in to their Facebook account 2 - 3 hours per day; 9 students (30\%) logged in less than 2 hours per day and 5 students (16.7\%) only logged in to their Facebook account less than an hour daily. Table 3 shows the competency level of students in using Facebook.

\subsection{The Effects of Using Facebook on Improving Students' Performance in Literature}

To answer the first research question, the researcher used the average grades for every students on the pre-test and the post-test as shown in Table 4.

Table 1. Length of time as a Facebook member.

\begin{tabular}{cccc}
\hline \multicolumn{2}{c}{ Years } & & Total \\
\hline & Less than a year & More than a year & \\
\hline Frequency & 2 & 28 & 30 \\
Percentage & $6.7 \%$ & $93.3 \%$ & $100 \%$ \\
\hline
\end{tabular}

Table 2. Frequency of logging into Facebook account.

\begin{tabular}{ccccc}
\hline & $\begin{array}{c}\text { Less than an } \\
\text { hour daily }\end{array}$ & $\begin{array}{c}\text { Less than } 2 \\
\text { hours per day }\end{array}$ & $\begin{array}{c}2-3 \text { hours } \\
\text { per day }\end{array}$ & Total \\
\hline $\begin{array}{c}\text { Frequency } \\
\text { Percentage }\end{array}$ & 5 & 9 & 16 & 30 \\
& $16.7 \%$ & $30.0 \%$ & $53.3 \%$ & $100 \%$ \\
\hline
\end{tabular}


To answer the main question of the study which is related to the effect of using Facebook in learning Literature, it is clear from Table 4 that the total

Table 3. Competency level in using Facebook.

\begin{tabular}{ccc}
\hline & Frequency & Percentage \\
\cline { 2 - 3 } Not Competent & 2 & $6.7 \%$ \\
Slightly competent & 5 & $16.7 \%$ \\
Competent & 7 & $23.3 \%$ \\
Highly competent & 16 & $53.3 \%$ \\
\hline Total & 30 & $100 \%$ \\
\hline
\end{tabular}

Table 4. The total average of the pre-test and the post-test grades distributed by the experimental group and control group.

\begin{tabular}{|c|c|c|c|c|c|c|c|}
\hline \multicolumn{3}{|c|}{ Control Group } & \multirow{2}{*}{ Serial } & \multicolumn{3}{|c|}{ Experimental Group } & \multirow{2}{*}{ Serial } \\
\hline Average & Posttest & Pretest & & Average & Posttest & Pretest & \\
\hline 23 & 23 & 23 & 1 & 26 & 27 & 25 & 1 \\
\hline 16.5 & 17 & 16 & 2 & 25 & 25 & 25 & 2 \\
\hline 20.5 & 22 & 19 & 3 & 23.5 & 26 & 21 & 3 \\
\hline 19.5 & 20 & 19 & 4 & 27.5 & 28 & 27 & 4 \\
\hline 21.5 & 22 & 21 & 5 & 20 & 21 & 19 & 5 \\
\hline 20 & 20 & 20 & 6 & 20.5 & 21 & 20 & 6 \\
\hline 22 & 22 & 22 & 7 & 19.5 & 21 & 18 & 7 \\
\hline 22 & 22 & 22 & 8 & 23 & 25 & 21 & 8 \\
\hline 24 & 24 & 24 & 9 & 23 & 24 & 22 & 9 \\
\hline 22 & 22 & 22 & 10 & 18 & 19 & 17 & 10 \\
\hline 21 & 20 & 22 & 11 & 20 & 23 & 17 & 11 \\
\hline 18.5 & 20 & 17 & 12 & 25.5 & 26 & 25 & 12 \\
\hline 21 & 21 & 21 & 13 & 24 & 25 & 23 & 13 \\
\hline 22.5 & 21 & 24 & 14 & 20 & 21 & 19 & 14 \\
\hline 18.5 & 19 & 18 & 15 & 25 & 26 & 24 & 15 \\
\hline 19 & 19 & 19 & 16 & 19 & 21 & 17 & 16 \\
\hline 21.5 & 22 & 21 & 17 & 20 & 22 & 18 & 17 \\
\hline 21.5 & 22 & 21 & 18 & 19.5 & 22 & 17 & 18 \\
\hline 22 & 22 & 22 & 19 & 20 & 21 & 19 & 19 \\
\hline 21.5 & 22 & 21 & 20 & 21.5 & 23 & 20 & 20 \\
\hline 19.5 & 20 & 19 & 21 & 18.5 & 20 & 17 & 21 \\
\hline 19.5 & 21 & 18 & 22 & 23.5 & 26 & 21 & 22 \\
\hline 20 & 23 & 17 & 23 & 21 & 25 & 17 & 23 \\
\hline 22.5 & 24 & 21 & 24 & 22.5 & 25 & 20 & 24 \\
\hline 22.5 & 24 & 21 & 25 & 21 & 24 & 18 & 25 \\
\hline 23.5 & 25 & 22 & 26 & 24.5 & 26 & 23 & 26 \\
\hline 20 & 21 & 19 & 27 & 22.5 & 25 & 20 & 27 \\
\hline 22.5 & 24 & 21 & 28 & 20 & 23 & 17 & 28 \\
\hline 21.5 & 23 & 20 & 29 & 22.5 & 26 & 19 & 29 \\
\hline 21.5 & 23 & 20 & 30 & 23 & 26 & 20 & 30 \\
\hline 20.9 & 21.1 & 20.7 & Average & 22.1 & 23.4 & 20.7 & Average \\
\hline
\end{tabular}


average of the pre-test is equal to the experimental group and the control group. On the other hand, the total average of the post-test of the experimental group is higher than the total average of the post-test of the control group. In addition to that, the total average of both pre-test and post-test of the experimental group was higher than the total average of the control group which means that the students in the experimental group are affected more than the students in the control group. The results showed a difference due to the intervention of Facebook to the experimental group between the average scores in pre and posttest. The results also showed that students after using Facebook were good in understanding the novel's events and they comprehended all questions in the post-test. It means that using Facebook in literature novel class is helpful for comprehension of the novel. The researchers found that Facebook is an effective tool that helped students in their level, and they recommended using Facebook as a helping tool or as an integrated tool with literature courses.

\subsection{Perception towards the Usage of Facebook in Learning Literature}

Table 5 presents the frequency data of the participants' perception towards the usage of Facebook in learning Literature.

The majority of the students have positive perception towards the use of $\mathrm{Fa}$ cebook in learning literature. It is seen that $92.5 \%$ of the students agreed that Facebook provides instant interaction (mean score $=3.20$ ). Total of $90 \%$ students agreed that Facebook enhances literacy skills (mean score $=3.42$ ), easy to use as a literature learning tool (mean score $=2.67$ ), easy to understand novel after the participation (mean score $=3.57$ ), help to answer the exercises easily (mean score $=3.67)$ and providing fun and interesting practice (mean score $=$ 3.52). Moreover, $85 \%$ of the students agreed that Facebook enhances their confidence level to read literature novel (mean score $=2.90$ ), creates comprehensive participation of students in learning literature (mean score $=2.75$ ), helps in organizing thought related to literature (mean score $=2.92$ ), helps in getting a better idea about literature novel (mean score $=2.82$ ), helps to get the characters, plots and themes of it (mean score $=3.70$ ) and Facebook helps widening the knowledge on literature novel (mean score $=3.12$ ). It further seen that $82.5 \%$ of the students agreed that Facebook enhances confidence level to learn literature (mean score $=2.90$ ), have ability to follow the events to get the ideas easily when using Facebook (mean score $=3.72$ ) and FB helps to increase the collaboration level between teachers and students (mean score $=3.25$ ). Almost $80 \%$ of the students agreed that Facebook enhances motivation towards literature (mean score -2.90 ), helps to learn from others' answers and participation (mean score $=3.00$ ), $\mathrm{FB}$ is more effective than classroom teaching (mean score $=3.37$ ), $\mathrm{FB}$ enhances learning effectiveness (mean score $=3.17$ ), flexible to interact with (mean score $=3.72$ ) and the use of FB make the respondents become skillful easily (mean score $=2.90$ ). It is also seen that $77.5 \%$ of the respondents agreed that Facebook helps in building a good rapport with other students (mean score $=$ 
Table 5. Perception towards the usage of Facebook.

\begin{tabular}{|c|c|c|c|c|c|c|}
\hline Questions & SD & $\mathrm{D}$ & $\mathrm{U}$ & A & SA & Mean \\
\hline 1) Facebook enhances my English literacy skills & 2.5 & 2.5 & 5 & 35.0 & 55.0 & 3.42 \\
\hline 2) Facebook enhances my confidence to learn Literature & 2.5 & 10 & 5 & 35 & 47.5 & 2.9 \\
\hline 3) Facebook enhances my confidence to read Literature novel & 5 & 7.5 & 2.5 & 27.5 & 57.5 & 2.9 \\
\hline 4) Facebook enhances my motivation towards literature & 5 & 7.5 & 7.5 & 27.5 & 52.5 & 2.9 \\
\hline 5) Facebook provides instant interaction & 0 & 5 & 2.5 & 42.5 & 50 & 3.2 \\
\hline 6) Facebook is easy to use as a Literature learning tool & 0 & 7.5 & 2.5 & 40 & 50 & 2.67 \\
\hline 7) Facebook gives courage to share moreinformation related Literature & 5 & 12.5 & 7.5 & 35 & 40 & 3.02 \\
\hline $\begin{array}{l}\text { 8) Facebook creates comprehensive participationof students in learning } \\
\text { Literature }\end{array}$ & 5 & 7.5 & 2.5 & 27.5 & 57.5 & 2.75 \\
\hline 9)Facebook helps in organizing thought related to Literature & 5 & 7.5 & 2.5 & 40 & 45 & 2.92 \\
\hline 10) Facebook helps in getting a better ideaabout Literature novel & 2.5 & 7.5 & 5 & 35.5 & 49.5 & 2.82 \\
\hline 11) It is easier to understand novel after the participation & 0 & 5 & 5 & 52.5 & 37.5 & 3.57 \\
\hline $\begin{array}{l}\text { 12) I have an ability to follow the events to get the ideas easily when using } \\
\text { Facebook }\end{array}$ & 2.5 & 7.5 & 7.5 & 37.5 & 45 & 3.72 \\
\hline $\begin{array}{l}\text { 13) Literature learning via Facebook helps me to get the characters, plots and } \\
\text { themes of it }\end{array}$ & 2.5 & 7.5 & 5 & 40 & 45 & 3.7 \\
\hline 14) Facebook helps me to answer the exercisesabout the novel easily & 0 & 5 & 5 & 45 & 45 & 3.67 \\
\hline 15) Facebook providing fun and interesting practice & 0.0 & 5 & 5 & 47.5 & 42.5 & 3.52 \\
\hline $\begin{array}{l}\text { 16) Learning Literature via Facebook helps widening my knowledge on } \\
\text { Literature novel }\end{array}$ & 5.0 & 7.5 & 2.5 & 35 & 50 & 3.12 \\
\hline 17) Learning from others' answers and participation & 7.5 & 5 & 7.5 & 35.5 & 44.5 & 3 \\
\hline 18) Facebook is more effective than classroom teaching & 7.5 & 2.5 & 10 & 37.5 & 42.5 & 3.37 \\
\hline 19) Building a good rapport with other students & 10.0 & 5 & 7.5 & 37.5 & 40 & 3.17 \\
\hline 20) Using Facebook increases my academic productivity towards Literature & 5.0 & 7.5 & 10 & 37.5 & 40 & 3.25 \\
\hline 21) Using Facebook enhances my learning Effectiveness & 5.0 & 10 & 5 & 45 & 35 & 3.17 \\
\hline 22) It is easy to get Facebook to do what I want it to do & 7.5 & 12.5 & 5 & 37.5 & 37.5 & 3.57 \\
\hline 23) Facebook is flexible to interact with & 2.5 & 7.5 & 10 & 40 & 40 & 3.72 \\
\hline 24) The activity on Facebook are clear and Understandable & 7.5 & 12.5 & 5 & 37.5 & 37.5 & 2.92 \\
\hline 25) It is easy for me to become skillful when using Facebook & 10.0 & 7.5 & 2.5 & 17.5 & 62.5 & 2.9 \\
\hline $\begin{array}{l}\text { 26) The use of Facebook helps me to interact and get feedback from the } \\
\text { teacher }\end{array}$ & 7.5 & 12.5 & 5 & 42.5 & 32.5 & 3.67 \\
\hline 27) I feel encouraged when friends "like" my comments & 5.0 & 12.5 & 7.5 & 32.5 & 42.5 & 3.12 \\
\hline 28) The level of communication among teachers and students increase & 7.5 & 12.5 & 5 & 47.5 & 27.5 & 3.37 \\
\hline $\begin{array}{l}\text { 29) The level of engagement between teachers and students increase while } \\
\text { using Facebook to learn literature }\end{array}$ & 2.5 & 12.5 & 7.5 & 47.5 & 30 & 3.67 \\
\hline $\begin{array}{l}\text { 30) The collaborations level increase between teachers and students while } \\
\text { using Facebook }\end{array}$ & 5.0 & 7.5 & 5 & 37.5 & 45 & 3.25 \\
\hline
\end{tabular}

3.17), FB increases academic productivity towards literature (mean score $=3.25$ ) and FB helps to increase the level of engagement between teachers and students (mean score $=3.67)$. Finally $75 \%$ of the students agreed that Facebook gives courage to share more information related to literature (mean score 3.02), helps to get what wanted the respondent to do easily (mean score $=3.57$ ), make the respondents clear and understandable (mean score $=2.92$ ), helps to interact and get feedback from the teacher (mean score $=3.67$ ), let the respondents feel en- 
couraged when friends like the comments (mean score $=3.12$ ) and $75 \%$ of them agreed that FB increases the level of communication among teachers and students (mean score $=3.37$ ).

\section{Discussion}

The main purpose of this study was to investigate the use of Facebook in literature class, especially in the novel class. The results indicate that Facebook is one of the powerful digital tool that have a real potential to positively affect student learning (Cook et al., 2008). Facebook is regarded as one of the most interesting applications that help in understanding English literature. It gives students the chance to understand events of stories, criticizes the stories. Students experience the language in the Facebook group in a lively way. With the refer to the prepost test; the researcher noticed that students' achievement is good to the intervention of using Facebook in understanding the novel. With regard to the first research question, the present study indicates that participant beliefs towards the general ease of use of Facebook in literature were overall positive. However, participant perceptions of Facebook actually diminished over the duration of the study. Regarding the second research question, the results suggested that participants' perceptions toward most statement items relating to specific activities through Facebook were largely positive both prior to and after completing the study. Again the quantitative data showed a strong favorable perception of using Facebook for specific activities.

\section{Conclusion}

Learning via Facebook does not only help to improve students' team working skills, but also helps them to achieve better results in learning. By using Facebook, students can get to know each other better and take education to its highest level and made it more interesting, therefore creating richer learning environments. It is suggested that the teachers should be more active in conducting activities in the Facebook group. This in turn will motivate the students to participate more. The design of the study plan also needs to be planned prior and ensure that all topics are involved in using Facebook in doing the activities. The educational institution should be aware of the capability of Facebook in supporting the process of teaching and learning. Thus, they should provide a better internet connection facility to the students and lecturers. Lack of access to participants was problematic to the study.

\section{References}

Blattner, G., \& Fiori, M. (2009). Facebook in the Language Classroom: Promises and Possibilities. International Journal of Instructional Technology and Distance Learning, 6, 17-28.

Boogart, M. R. V. (2006). Uncovering the Social Impacts of Facebook on a College Campus. Doctoral Dissertation, Manhattan, KS: Kansas State University.

Bugeja, M. J. (2006). Facing the Facebook. Chronicle of Higher Education, 52, C1. 
Chapelle, C. (2003). English Language Learning and Technology: Lectures on Applied Linguistics in the Age of Information and Communication Technology (Vol. 7). Amsterdam: John Benjamins Publishing. https://doi.org/10.1075/lllt.7

Chen, P. S. D., Lambert, A. D., \& Guidry, K. R. (2010). Engaging Online Learners: The Impact of Web-Based Learning Technology on College Student Engagement. Computers \& Education, 54, 1222-1232.

Cook, C., Fisher, T., Graber, R., Harrison, C., Lewin, C., Logan, C., Luckin, R., Oliver, M., \& Sharples, M. (2008). Web 2.0 Technologies for Learning: The Current LandscapeOpportunities, Challenges and Tensions. BECTA Research Report.

Ellison, N. B., Steinfield, C., \& Lampe, C. (2007). The Benefits of Facebook "Friends:" Social Capital and College Students' Use of Online Social Network Sites. Journal of Computer-Mediated Communication, 12, 1143-1168.

https://doi.org/10.1111/j.1083-6101.2007.00367.x

Facebook (2013). Key Facts. Facebook. https://newsroom.fb.com/company-info/

Grabmeier, J. (2009). Study Finds Link between Facebook Use, Lower Grades in College. Ohio State University. http://researchnews.osu.edu/archive/facebookusers.htm

Hamid, S., Waycott, J., Chang, S., \& Kurnia, S. (2011). Appropriating Online Social Networking (OSN) Activities for Higher Education: Two Malaysian Cases. Proceedings of ASCILITE-Australian Society for Computers in Learning in Tertiary Education Annual Conference, 526-538.

Hurt, N. E., Moss, G. S., Bradley, C. L., Larson, L. R., Lovelace, M., Prevost, L. B. et al. (2012). The "Facebook" Effect: College Students' Perceptions of Online Discussions in the Age of Social Networking. International Journal for the Scholarship of Teaching and Learning, 6, Article 10. https://doi.org/10.20429/ijsotl.2012.060210

Junco, R., Heiberger, G., \& Loken, E. (2011). The Effect of Twitter on College Student Engagement and Grades. Journal of Computer Assisted Learning, 27, 119-132. https://doi.org/10.1111/j.1365-2729.2010.00387.x

Kabilan, M. K., Ahmad, N., \& Abidin, M. J. Z. (2010). Facebook: An Online Environment for Learning of English in Institutions of Higher Education? The Internet and Higher Education, 13, 179-187.

Kirschner, P. A., \& Karpinski, A. C. (2010). Facebook ${ }^{\circledR}$ and Academic Performance. Computers in Human Behavior, 26, 1237-1245.

Lenhart, A., Purcell, K., Smith, A., \& Zickuhr, K. (2010). Social Media \& Mobile Internet Use among Teens and Young Adults. Pew Internet \& American Life Project.

Lim, T. (2010). The Use of Facebook for Online Discussions among Distance Learners. Turkish Online Journal of Distance Education, 11, 72-81.

Luke, C. L. (2006). Situating CALL in the Broader Methodological Context of Foreign Language Teaching and Learning: Promises and Possibilities. In L. Ducate, \& N. Arnold (Eds.), Calling on CALL: From Theory and Research to New Directions in Foreign Language Teaching (pp. 21-42). San Marcos, TX: Computer Assisted Language Instruction Consortium (CALICO).

Madge, C., Meek, J., Wellens, J., \& Hooley, T. (2009). Facebook, Social Integration and Informal Learning at University: "It Is More for Socialising and Talking to Friends about Work than for Actually Doing Work". Learning, Media and Technology, 34, 141-155. https://doi.org/10.1080/17439880902923606

Noyes, J. S. (2015). Universal Chalcidoidea Database. World Wide Web Electronic Publication. http://www.nhm.ac.uk/chalcidoids

Roblyer, M. D., McDaniel, M., Webb, M., Herman, J., \& Witty, J. V. (2010). Findings on Facebook in Higher Education: A Comparison of College Faculty and Student Uses and 
Perceptions of Social Networking Sites. The Internet and Higher Education, 13, 134140.

Roth, A. (2009). Following Plato's Advice: Pedagogy and Technology for the Facebook Generation. Journal of Philosophy and History of Education, 59, 125-128.

Sidhu, G. K. (2003). Literature in the Language Classroom: Seeing through the Eyes of Learners (pp. 88-110). Teaching of Literature in ESL/EFL Contexts.

Simpson, M. N. (2012). ESL@ FACEBOOK: A Teacher’s Diary on Using Facebook. Teaching English with Technology, No. 3, 36-48.

Slonje, R., Smith, P. K., \& Frisé, N. A. (2013). The Nature of Cyberbullying, and Strategies for Prevention. Computers in Human Behavior, 29, 26-32.

Zhao, S., Grasmuck, S., \& Martin, J. (2008). Identity Construction on Facebook: Digital Empowerment in Anchored Relationships. Computers in Human Behavior, 24, 18161836. 


\section{Appendix}

\section{Questionnaire}

Part A: Demographic Information

Please complete the following

a) Gender:

1. $\mathrm{M}$

2. F

b) First language:
1. Malay
2. Chinese
3. Tamil
4. English

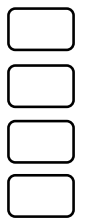

c) English Language proficiency: 1. Competent user

2. Good user

3. Very good user

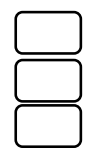

d) Do you have a Facebook account?:

1. Yes

2. No

e) Length of time as a Facebook member:

1. Less than a year

2. More than a year

f) Frequency of logging in to Facebook: 1. Less than an hour daily

2. Less than 2 hours per day

3. 2 - 3 hours per day

4. Once or twice per week

g) Level of competency when using Facebook: 1. Not competent

2. Somewhat competent

3. Uncertain

4. Competent

5. Highly competent

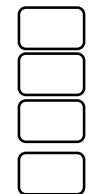


Part B: Perceptions towards the Usage of Facebook in Learning Literature

Please respond to the following statements and circle your answers on the rating scale of 1 to 5 , where $1=$ strongly disagree, 2 = disagree, $3=$ undecided, $4=$ agree and $5=$ strongly agree.

1) Facebook enhances my English literacy skills

2) Facebook enhances my confidence to learn literature

3) Facebook enhances my confidence to read literature novels

4) Facebook increases my motivation towards literature

5) Facebook provides instant interaction

6) Facebook is easy to use as a Literature learning tool

7) Facebook gives courage to share more information related to Literature

8) Facebook creates comprehensive participation of students in learning Literature

9) Facebook helps in organizing thought related to Literature

10) Facebook helps in getting a better idea about Literature novel

11) It is easier to understand novel after the participation

12) I have an ability to follow the events to get the ideas easily when using Facebook

13) Literature learning via Facebook helps me to know the characters, plots and themes of it 14) Facebook helps me to answer the exercises about the novel easily

15) Facebook providing fun and interesting practice

16) Learning Literature via Facebook helps widening my knowledge on Literature novel

17) Learning from others' answers and participation

18) Building a good rapport with other students

19) Using Facebook make me more enthusiasticq

20) Using Facebook increases my academic productivity towards Literature

21) Using Facebook enhances my learning effectiveness

$\begin{array}{lllll}1 & 2 & 3 & 4 & 5 \\ 1 & 2 & 3 & 4 & 5\end{array}$

$\begin{array}{lllll}1 & 2 & 3 & 4 & 5\end{array}$

$\begin{array}{lllll}1 & 2 & 3 & 4 & 5\end{array}$

$\begin{array}{lllll}1 & 2 & 3 & 4 & 5\end{array}$

$\begin{array}{lllll}1 & 2 & 3 & 4 & 5\end{array}$

$\begin{array}{lllll}1 & 2 & 3 & 4 & 5\end{array}$

$\begin{array}{lllll}1 & 2 & 3 & 4 & 5\end{array}$

$\begin{array}{lllll}1 & 2 & 3 & 4 & 5\end{array}$

$\begin{array}{lllll}1 & 2 & 3 & 4 & 5\end{array}$

$\begin{array}{lllll}1 & 2 & 3 & 4 & 5\end{array}$

$\begin{array}{lllll}1 & 2 & 3 & 4 & 5\end{array}$

$\begin{array}{lllll}1 & 2 & 3 & 4 & 5\end{array}$

$\begin{array}{lllll}1 & 2 & 3 & 4 & 5\end{array}$

$\begin{array}{lllll}1 & 2 & 3 & 4 & 5\end{array}$

$\begin{array}{lllll}1 & 2 & 3 & 4 & 5\end{array}$

$\begin{array}{lllll}1 & 2 & 3 & 4 & 5\end{array}$

$\begin{array}{lllll}1 & 2 & 3 & 4 & 5\end{array}$

$\begin{array}{lllll}1 & 2 & 3 & 4 & 5\end{array}$

$\begin{array}{lllll}1 & 2 & 3 & 4 & 5\end{array}$

$\begin{array}{lllll}1 & 2 & 3 & 4 & 5\end{array}$ 
22) It is easy to get Facebook to do what

I want it to do

23) Facebook is flexible to interact with

24) The activity on Facebook are clear and Understandable

25) It is easy for me to become skillful when using Facebook

26) The use of Facebook helps me to interact and get feedback from the teacher

27) I feel encouraged when friends "like" my comments

28) The level of communication among teachers and students increase

29) The level of engagement between teachers and students increase while using Facebook to

30) The collaborations level increase between

teachers and students while using Facebook to learn literature

$\begin{array}{lllll}1 & 2 & 3 & 4 & 5 \\ 1 & 2 & 3 & 4 & 5 \\ 1 & 2 & 3 & 4 & 5 \\ 1 & 2 & 3 & 4 & 5 \\ 1 & 2 & 3 & 4 & 5 \\ 1 & 2 & 3 & 4 & 5 \\ 1 & 2 & 3 & 4 & 5 \\ 1 & 2 & 3 & 4 & 5\end{array}$

literature

345 Scientific Research Publishing

Submit or recommend next manuscript to SCIRP and we will provide best service for you:

Accepting pre-submission inquiries through Email, Facebook, LinkedIn, Twitter, etc. A wide selection of journals (inclusive of 9 subjects, more than 200 journals)

Providing 24-hour high-quality service

User-friendly online submission system

Fair and swift peer-review system

Efficient typesetting and proofreading procedure

Display of the result of downloads and visits, as well as the number of cited articles

Maximum dissemination of your research work

Submit your manuscript at: http://papersubmission.scirp.org/

Or contact ce@scirp.org 